\title{
CONFIRMATION, SERVICE QUALITY, DAN QUALITY OF PERSONALIZATION UNTUK MEMPREDIKSI KEPUASAN PELANGGAN
}

\author{
Delvin Valentino Agustinus dan Keni Keni \\ Program Studi Manajemen, Fakultas Ekonomi Universitas Tarumanagara, Jakarta \\ E-mail: Delvin.115170178@stu.untar.ac.id
}

\begin{abstract}
The purpose of this study is to examine whether confirmation, service quality, and personalization quality can predict customer satisfaction. This study is classified as a descriptive research, whereas the data collection was done by using cross-sectional method. This study conducted non-probability sampling, in which convenience sampling method was used to collect data from a total sample of 150 respondents. Data analysis was conducted by using the Smart Partial Least Square (SPLS) software version 3.00. The results of this study indicate that confirmation, service quality, and personalization quality can predict customer satisfaction positively.
\end{abstract}

Keywords: confirmation, service quality, quality of personalization, customer satisfaction

Abstrak: Tujuan penelitian ini adalah untuk menguji apakah confirmation, service quality, dan quality of personalization dapat memprediksi kepuasan pelanggan. Penelitian ini diklasifikasikan sebagai penelitian deskriptif, dimana pengumpulan data dilakukan dengan menggunakan metode cross-sectional. Penelitian ini menerapkan non-probability sampling dengan metode convenience sampling untuk mengumpulkan data dari 150 responden. Analisis data dilakukan dengan menggunakan perangkat lunak Smart Partial Least Square (SPLS) versi 3.00. Hasil penelitian ini menunjukkan bahwa confirmation, service quality, dan personalization quality dapat secara positif memprediksi kepuasan pelanggan.

Kata kunci: konfirmasi, kualitas layanan, kualitas personalisasi, kepuasan pelanggan

\section{LATAR BELAKANG}

Perkembangan teknologi yang disertai dengan internet telah berperan penting dalam kehidupan masyarakat, seperti penyedia informasi yang sangat beragam, pengembangan komunikasi jarak jauh, akses transportasi, dan bahkan berbelanja secara online. Perkembangan tersebut telah mengubah pola pikir masyarakat Indonesia mengenai belanja online, dari yang awalnya merasa ragu untuk berbelanja secara online menjadi negara dengan penggemar belanja online urutan pertama di dunia (We Are Social, 2021).

Seiring dengan peningkatan belanja online tersebut, e-commerce di Indonesia juga berkembang dengan sangat pesat yang ditunjukkan dengan tingkat pertumbuhan e-commerce yang mencapai lebih dari 30\% pada tahun 2020 (Kominfo, 2021). Kehadiran e-commerce diharapkan dapat membantu pelaku usaha dalam melakukan kegiatan jual beli, tetapi pelaku usaha juga harus menghadapi persaingan yang semakin meningkat. Oleh sebab itu, penelitian mengenai kepuasan pelanggan menjadi diperlukan oleh para pelaku usaha online untuk mengetahui faktor-faktor yang dapat meningkatkan kepuasan pelanggan sebagai sebuah upaya untuk mengembangkan daya saing. 
Kepuasan pelanggan menurut Kotler dan Keller (2016) merupakan suatu perasaan senang atau kecewa yang dirasakan oleh konsumen terhadap produk atau jasa yang bersumber dari perbandingan manfaat yang dirasakan dari suatu produk atau jasa dengan manfaat yang diharapkan oleh konsumen.

Menurut Khakim, Fathoni dan Minarsih (2015), service quality, price dan trust dapat memprediksi kepuasan pelanggan secara positif dan signifikan. Chow dan Shi (2014) mengemukakan bahwa confirmation secara langsung dapat memprediksi kepuasan pelanggan. Menurut Dewi (2017), terdapat variabel personalization yang memprediksi satisfaction secara signifikan. Tata, Prashar dan Parsad (2020), mengemukakan bahwa confirmation, service quality dan quality of personalization dapat memprediksi satisfaction secara positif dan signifikan. Berdasarkan latar belakang di atas, penelitian ini bertujuan untuk mengkaji prediksi confirmation, service quality, dan quality of personalization terhadap kepuasan pelanggan.

\section{KAJIAN TEORI}

Penelitian ini didasarkan pada dua teori, yaitu Expectation Confirmation Theory (ECT) yang diperkenalkan oleh Oliver (1980) dan regret theory yang diperkenalkan oleh Loomes dan Sugden (1982).

ECT menjelaskan bahwa intensi konsumen untuk membeli kembali sebuah produk atau jasa secara signifikan dipengaruhi oleh pengalaman ketika menggunakan produk atau jasa tersebut. Jika konsumen merasa puas dengan pengalaman tersebut, maka konsumen akan memiliki kecenderungan yang lebih tinggi untuk melakukan pembelian kembali.

Sementara itu, regret theory menjelaskan bahwa ketika seorang individu memiliki beberapa alternatif produk atau jasa, individu tersebut akan mengkhawatirkan mengenai penyesalan yang dapat terjadi jika merasa bahwa alternatif yang dipilih bukan merupakan alternatif yang terbaik, sehingga pengambilan keputusan pembelian menjadi dipengaruhi oleh pertimbangan untuk menghindari penyesalan tersebut.

Berdasarkan ECT dan regret theory, dapat disimpulkan bahwa pengalaman konsumen dalam mengkonsumsi suatu produk atau jasa akan mempengaruhi keputusan konsumen dan konsumen mengkhawatirkan mengenai penyesalan yang dapat terjadi jika merasa bahwa alternatif yang dipilih bukan merupakan alternatif yang terbaik. Oleh sebab itu, beberapa faktor, seperti confirmation, service quality, dan quality of personalization dapat berpengaruh terhadap pengalaman konsumen dalam menggunakan produk atau jasa dan sekaligus berperan dalam meyakinkan konsumen dalam pengambilan keputusan pembelian yang kemudian dapat memotivasi konsumen untuk melakukan pembelian.

\section{Confirmation}

Menurut Oghuma et al. (2016: 37), "Confirmation is the extent to which the actual use experience confirms one's initial expectation". Konfirmasi adalah sejauh mana pengalaman konsumen dalam menggunakan suatu produk atau jasa dapat mengkonfirmasi ekspektasi konsumen sebelum menggunakan produk tersebut. Sementara itu, Wang dan Wang (2019) berpendapat bahwa konfirmasi mengimplikasikan tingkat seorang individu merasakan keuntungan yang diharapkan dari sebuah produk pada saat menggunakan produk tersebut. Berdasarkan beberapa argumentasi di atas, penelitian ini menyimpulkan confirmation sebagai tingkat seorang individu merasakan keuntungan yang diharapkan dari sebuah produk pada saat menggunakan produk tersebut. 


\section{Service quality}

Menurut Yousapronpaiboon (2014: 1089) "service quality can be defined as a comparison between customer's expectation of the service that they will get from a company and the actual service or performance that the company provides them". Kualitas layanan dapat didefinisikan sebagai suatu perbandingan antara harapan konsumen terhadap layanan yang akan konsumen dapatkan dari suatu perusahaan dan layanan atau kinerja aktual yang diberikan dari perusahaan kepada konsumennya, sementara Oscar dan Keni (2019) mendefinisikan service quality sebagai suatu penilaian dari pelanggan terhadap pelayanan yang didapat dari perusahaan ketika membeli suatu produk dari perusahaan tersebut. Selain itu, Maria, Wijaya dan Keni (2021) mendefinisikan service quality sebagai estetika respon dari penjual dalam mengirim produk secara cepat dan aman. Berdasarkan beberapa pendapat di atas, penelitian ini mendefinisikan service quality sebagai penilaian pelanggan terhadap pelayanan yang diperoleh dari perusahaan ketika membeli suatu produk dari perusahaan tersebut.

\section{Quality of personalization}

Ball, Coelho dan Vilares (2006: 391) mendefinisikan personalization sebagai “. . . any creation or adjustment of a service to fit individual requirements of a customer". Personalization merupakan suatu penyesuaian terhadap layanan atau produk supaya dapat sesuai dengan kebutuhan konsumen dan harapan yang diinginkan oleh konsumen dapat terpenuhi.

\section{Kepuasan pelanggan}

Menurut Kotler dan Keller (2016:131), kepuasan pelanggan merupakan suatu perasaan senang atau kecewa konsumen terhadap produk atau jasa yang dihasilkan dari suatu perusahaan dengan membandingkan hasil yang diberikan dengan harapan yang diinginkan konsumen, sementara menurut Juliana dan Keni (2020), kepuasan pelanggan merupakan suatu respon positif yang dirasakan oleh pelanggan setelah terjadinya pembelian dan penggunaan layanan. Lebih lanjut, Sutanto dan Keni (2020) berpendapat bahwa kepuasan merupakan perbandingan harapan pelanggan terhadap suatu produk dengan hasil yang diperoleh pelanggan dari produk tersebut. Berdasarkan beberapa definisi di atas, penelitian ini menyimpulkan kepuasan pelanggan sebagai perbandingan harapan pelanggan terhadap suatu produk dengan hasil yang diperoleh dari produk tersebut.

\section{Kaitan antara confirmation dan kepuasan pelanggan}

Penelitian Chow dan Shi (2014) menyimpulkan bahwa confirmation memiliki hubungan yang positif dan secara langsung dapat memprediksi kepuasan pelanggan karena ketika harapan konsumen dapat terkonfirmasi oleh perusahaan, maka kepuasan konsumen akan meningkat. Selain itu, penelitian Hsu dan Lin (2015), mengemukakan bahwa terdapat hubungan yang positif antara confirmation dengan kepuasan. Berdasarkan pemaparan di atas, hipotesis pertama dalam penelitian ini adalah sebagai berikut.

H1: Confirmation secara positif dapat digunakan untuk memprediksi kepuasan pelanggan.

\section{Kaitan antara service quality dan kepuasan pelanggan}


Hasil penelitian Khakim, Fathoni dan Minarsih (2015) menunjukkan bahwa service quality dapat memprediksi satisfaction secara positif dan signifikan. Penelitian tersebut menjelaskan bahwa jika suatu marketplace online ingin bertahan, bersaing dan berkembang, maka harus mampu memenuhi dan memberikan kualitas pelayanan yang diharapkan dan diinginkan oleh konsumen. Febrianti dan Keni (2020) mengemukakan bahwa service quality dapat memprediksi kepuasan pelanggan secara positif. Berdasarkan pemaparan di atas, hipotesis kedua dalam penelitian ini adalah sebagai berikut.

H2: Service quality secara positif dapat digunakan untuk memprediksi kepuasan pelanggan.

\section{Kaitan antara quality of personalization dan kepuasan pelanggan}

Pada penelitian Tata, Prashar dan Parsad (2020), ditunjukkan bahwa quality of personalization dapat memprediksi kepuasan pelanggan secara positif dan signifikan karena marketplace online dapat meningkatkan fitur untuk memfasilitasi pembeli dalam membuat keputusan pembelian. Peningkatan personalisasi dengan baik pada suatu layanan atau produk marketplace online akan meningkatkan kepuasan konsumen. Hasil penelitian tersebut konsisten dengan hasil penelitian Dewi (2017) yang menunjukkan bahwa quality of personalization merupakan prediktor kepuasan pelanggan secara positif dan signifikan, sehingga ketika quality of personalization ditingkatkan, maka dapat meningkatan kepuasan. Berdasarkan pemaparan di atas, hipotesis ketiga dalam penelitian ini adalah sebagai berikut.

H3: Quality of personalization secara positif dapat digunakan untuk memprediksi kepuasan pelanggan.

Berdasarkan uraian mengenai kaitan antarvariabel, maka kerangka pemikiran pada penelitian ini adalah sebagai berikut:

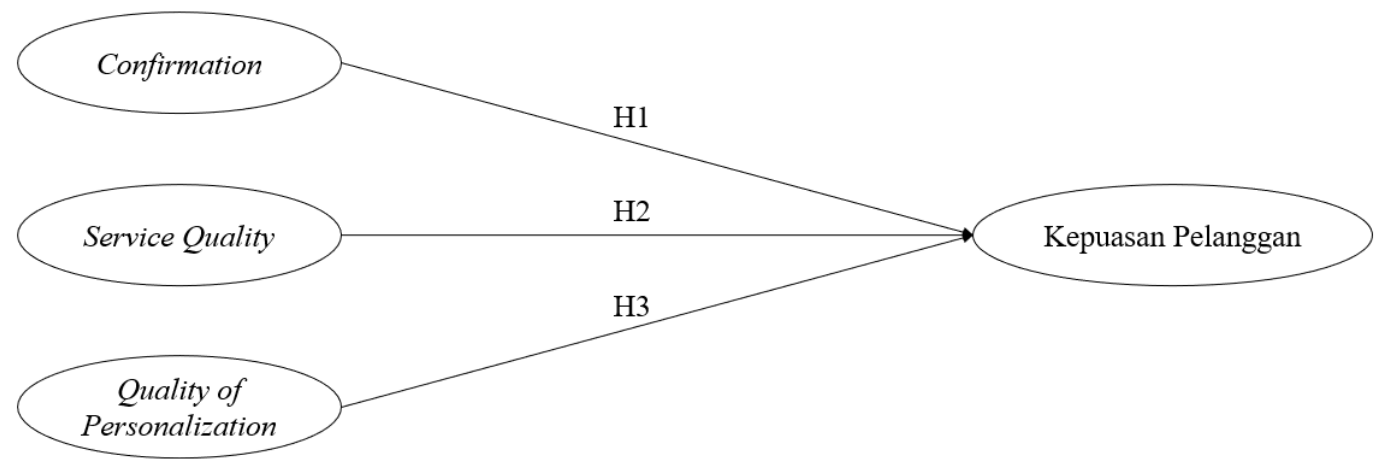

Gambar 1. Kerangka Pemikiran

\section{METODOLOGI}

Penelitian ini merupakan penelitian deskriptif yang bertujuan untuk menjelaskan karakteristik atau tujuan pasar (Malhotra, 2015) dengan pengumpulan data dilakukan secara cross-sectional. Pengambilan sampel dilakukan secara non-probability sampling dengan teknik convenience sampling pada 150 responden. Pengumpulan data dilakukan dengan menggunakan kuesioner online yang didistribusikan melalui Google Form dengan skala yang 
digunakan adalah skala Likert 5 poin. Sementara itu, analisis data dilakukan dengan menggunakan software Smart Partial Least Square (SPLS) versi 3.00.

Pengukuran variabel dalam penelitian ini menggunakan indikator pada penelitian terdahulu yang ditunjukkan pada Tabel 1 sebagai berikut:

Tabel 1. Indikator Variabel Penelitian

\begin{tabular}{|l|c|c|}
\hline \multicolumn{1}{|c|}{ Variabel } & Jumlah Indikator & \multirow{2}{*}{ Sumber } \\
\hline Confirmation & 5 & \multirow{3}{*}{$\begin{array}{c}\text { Tata, Prashar dan } \\
\text { Parsad (2020) }\end{array}$} \\
\cline { 1 - 2 } Service quality & 4 & \\
\hline Quality of personalization & 3 & \\
\hline
\end{tabular}

\section{HASIL ANALISIS DATA}

Analisis data pertama yang dilakukan adalah pengujian outer model untuk menguji validitas dan reliabilitas data yang diperoleh dari responden. Analisis validitas dapat dilakukan dengan menggunakan convergent validity dan discriminant validity. Hasil analisis convergent validity menunjukkan bahwa nilai AVE masing-masing variabel adalah $\geq 5$ dan nilai outer loading masing-masing variabel $>0,7$. Selanjutnya, pada pengujian discriminant validity nilai Fornell-Larcker harus lebih tinggi dari korelasi antar konstruk (Hair et al, 2013), dimana hasil pengujian menunjukkan bahwa nilai Fornell-Larcker telah memenuhi kriteria tersebut. Lebih lanjut, nilai cross loading yang dihasilkan lebih tinggi daripada variabel lain, sehingga hasil pengujian cross loading menunjukkan bahwa nilai dari semua indikator memenuhi syarat (Henseler et al., 2009).

Analisis reliabilitas dapat dilakukan dengan mengamati Cronbach's alpha dan composite reliability. Cronbach's alpha dapat dikatakan reliabel apabila nilainya > 0,6 (Malhotra, 2015), sementara composite reliability dapat dikatakan reliabel apabila nilainya $>0,7$. Dalam penelitian ini, nilai Cronbach's alpha dan composite reliability pada setiap variabel lebih besar dari 0,6 dan 0,7, sehingga seluruh variabel penelitian telah memenuhi syarat reliabilitas.

Selanjutnya, pengujian inner model dilakukan untuk menguji hipotesis dengan menggunakan pengujian coefficient determinant $\left(\mathrm{R}^{2}\right)$, uji effect size $\left(\mathrm{F}^{2}\right)$, uji Chi-square $\left(Q^{2}\right)$, uji kecocokan model (Goodness of Fit / GoF), hasil perhitungan path-coefficient dan pengujian hipotesis penelitian. Pengujian yang pertama adalah uji $R^{2}$ dengan nilai sebesar 0,632 atau setara dengan $63,2 \%$ yang memiliki sifat sedang. Nilai $R^{2}$ tersebut menunjukkan bahwa variabel confirmation, service quality dan quality of personalization dapat menjelaskan variabel kepuasan pelanggan sebanyak $63,2 \%$, sementara sisanya dijelaskan oleh variabel yang lain.

Hasil pengujian $f^{2}$ menunjukkan bahwa variabel confirmation memiliki efek lemah terhadap nilai $f$-square pada variabel kepuasan pelanggan. Selanjutnya, variabel service quality memiliki efek lemah terhadap nilai $f$-square pada variabel kepuasan pelanggan, sementara variabel quality of personalization memiliki efek sedang terhadap variabel kepuasan pelanggan.

Hasil pengujian $Q^{2}$ menunjukkan bahwa nilai $Q^{2}$ terhadap variabel kepuasan pelanggan sebesar 0,477, dimana nilai tersebut lebih besar dari 0 yang menunjukkan bahwa confirmation, service quality dan quality of personalization dapat menjelaskan variabel kepuasan pelanggan dengan baik. 
Hasil pengujian GoF menunjukkan bahwa nilai Gof sebesar 0,6777, yang tergolong dalam kategori besar, sehingga dapat dinyatakan bahwa model penelitian ini memiliki tingkat kesesuaian dan kecocokan.

Hasil pengujian path-coefficient menunjukkan bahwa confirmation, service quality dan quality of personalization mempengaruhi kepuasan pelanggan secara positif,. Selanjutnya, hasil analisis data ditunjukkan pada Tabel 2 sebagai berikut.

Tabel 2. Hasil pengujian hipotesis

\begin{tabular}{|c|l|c|c|c|}
\hline \multicolumn{2}{|c|}{ Hipotesis } & Path-Coefficient & t-statistic & p-values \\
\hline H1 & $\begin{array}{l}\text { Confirmation } \rightarrow \text { kepuasan } \\
\text { pelanggan }\end{array}$ & 0,411 & 5,095 & 0,000 \\
\hline H2 & $\begin{array}{l}\text { Service quality } \rightarrow \text { kepuasan } \\
\text { pelanggan }\end{array}$ & 0,181 & 2,174 & 0,030 \\
\hline H3 & $\begin{array}{l}\text { Quality of personalization } \\
\rightarrow \text { kepuasan pelanggan }\end{array}$ & 0,330 & 4,908 & 0,000 \\
\hline
\end{tabular}

Pengujian hipotesis yang ditunjukkan pada tabel 2 dilakukan dengan mengamati $p$-value dan $t$-value. Sebuah hipotesis dapat didukung dan diterima jika memiliki $p$-value yang lebih kecil dari 0,05 . Selain itu, hipotesis tersebut dapat didukung dan diterima jika memiliki $t$-value yang lebih besar dari 1,96.

\section{PEMBAHASAN}

Hasil pengujian hipotesis pertama menunjukkan bahwa confirmation secara positif dapat digunakan untuk memprediksi kepuasan pelanggan. Hasil tersebut konsisten dengan penelitian yang dilakukan oleh Hsu dan Lin (2015); Chow dan Shi (2014); Oghuma et al (2016); Hsu dan Lin (2015). Chow dan Shi. (2014) menyatakan bahwa confirmation akan membantu pembeli dalam melakukan pengajuan ketika mengalami kendala terkait pembeliannya. Jika pengajuan tersebut terkonfirmasi, maka harapan konsumen akan terpenuhi dan merasa puas. Selanjutnya, Oghuma et al. (2016) berpendapat bahwa jika konsumen merasakan kesesuaian dengan produk atau layanan yang diterima, maka konsumen akan merasa puas.

Hasil pengujian hipotesis kedua menunjukkan bahwa service quality secara positif dapat digunakan untuk memprediksi kepuasan pelanggan. Hasil tersebut konsisten dengan penelitian Khakim, Fathoni dan Minarsih (2015); Amryyanti dan Sukaatmadja (2013); Khamis dan Abrashid (2018). Khakim, Fathoni dan Minarsih (2015) mengemukakan bahwa marketplace harus mampu memenuhi dan memberikan kualitas pelayanan yang diharapkan dan diinginkan oleh konsumen. Jika marketplace online tidak dapat memenuhi keinginan konsumen terkait kualitas pelayanan yang baik, maka tidak akan tercipta kepuasan konsumen dan marketplace tersebut akan ditinggalkan oleh konsumen. Selanjutnya, Amryyanti dan Sukaatmadja (2013) menjelaskan bahwa layanan yang berkualitas akan mengarah kepada kepuasan konsumen karena memenuhi keinginan dan harapan konsumen tersebut. Dengan demikian, dapat disimpulkan bahwa kualitas pelayanan yang baik akan meningkatkan kepuasan pelanggan, sementara layanan yang tidak baik akan mengurangi tingkat kepuasan pelanggan.

Hasil pengujian hipotesis ketiga menunjukkan bahwa quality of personalization secara positif dapat digunakan untuk memprediksi kepuasan pelanggan. Hasil tersebut konsisten dengan penelitian yang dilakukan oleh Dewi (2017); Tata, Prashar dan Parsad (2020). Tata, Prashar dan Parsad (2020) menjelaskan bahwa mempersonalisasi suatu produk atau perusahaan 
dapat meningkatkan kepuasan pelanggan setelah melakukan pembelian. Selanjutnya, Selain itu, Tata, Prashar dan Parsad (2020) mengemukakan bahwa marketplace online dapat meningkatkan fitur untuk memfasilitasi pembeli dalam membuat keputusan pembelian, serta meningkatkan personalisasi dengan baik pada suatu layanan atau produk marketplace online untuk menciptakan kepuasan konsumen.

\section{KESIMPULAN}

Penelitian ini menyimpulkan bahwa confirmation, service quality, dan quality of personalization secara positif dapat digunakan untuk memprediksi kepuasan pelanggan. Berdasarkan kesimpulan tersebut, penelitian ini menyarankan perusahaan untuk mengembangkan dan mempertahankan user experience yang sudah baik dengan secara konsisten mengamati dan mempelajari ekspektasi pelanggan terhadap perusahaan, seperti penyediaan barang dan layanan yang baik, serta manfaat yang dapat diberikan kepada pelanggan, sehingga ekspektasi tersebut dapat terpenuhi dengan baik dan meningkatkan kepuasan pelanggan. Selain itu, perusahaan perlu mengkaji pertanyaan-pertanyaan yang disampaikan oleh pelanggan, sehingga perusahaan dapat menyediakan jawaban yang tepat jika pertanyaan yang serupa ditanyakan kembali pada masa mendatang. Sementara itu, untuk penelitian selanjutnya, disarankan untuk melakukan penelitian terhadap kepuasan pelanggan dengan variabel independen yang lain, seperti harga dan kepercayaan (Khakim, Fathoni \& Minarsih, 2015).

\section{DAFTAR PUSTAKA}

Amryyanti, R., Sukaatmadja, I. P. G. \& Cahya, K. N. (2013). Pengaruh Kualitas Layanan, Produk dan Kewajaran Harga Terhadap Kepuasan dan Loyalitas Pelanggan Pada LnC Skin Care Singaraja. Journal Ekonomi dan Bisnis, 2(1), 22-29.

Ball, D., Coelho, P. S., \& Vilares, M. J. (2006). Service personalization and loyalty. Journal of services marketing. https://doi.org/10.1108/08876040610691284

Chow, W. S., \& Shi, S. (2014). Investigating students' satisfaction and continuance intention toward e-learning: An Extension of the expectation-confirmation model. ProcediaSocial and Behavioral Sciences, 141, 1145-1149 https://doi.org/10.1016/j.sbspro.2014.05.193

Dewi, R. (2017). PENGARUH IMPLEMENTASI E-SERVICE QUALITY TERHADAP KEPUASAN PELANGGAN DI EZYTRAVEL: survey terhadap pelanggan ezytravel yang menggunakan website di indonesia (Doctoral dissertation, Universitas Pendidikan Indonesia).

Febrianti, I. N. \& Keni (2021). Pengaruh Experiential Marketing dan Service Quality terhadap Customer Loyalty: Customer Satisfaction sebagai Variabel Mediasi. Jurnal Managemen Bisnis dan Kewirausahaan, 5(1), 56-61. http://dx.doi.org/10.24912/jmbk.v5i1.10400

Hair, J. F., Ringle, C. M. \& Sarstedt, M. (2013). Partial Least Squares Structural Equation Modeling: Rigorous Applications, Better Results and Higher Acceptance. Long Range Planning, 46(1-2), 1-12.

Henseler, J., Ringle, C. M. \& Sinkovics, R. R. (2009). The Use of Partial Least Squares Path Modeling in International Marketing. Advances in International Marketing, 277-319. https://doi.org/10.1108/S1474-7979(2009)0000020014 
Hsu, C. L. and Lin, J. C. C. (2015). "What drives purchase intention for paid mobile apps?-An expectation confirmation model with perceived value", Electronic Commerce Research and Applications, Vol. 14 No. 1, pp. 46-57. https://doi.org/10.1016/j.elerap.2014.11.003

Juliana \& Keni. (2020). Prediksi Kualitas Pelayanan Dan Kepercayaan Terhadap Loyalitas Pelanggan: Kepuasan Pelanggan Sebagai Variabel Mediasi. Jurnal Manajerial Dan Kewirausahaan, 2(1), 110-121

Khakim, L., Fathoni, A., \& Minarsih, M. M. (2015). Pengaruh kualitas pelayanan, harga dan kepercayaan terhadap loyalitas pelanggan dengan variabel kepuasan pelanggan sebagai variabel intervening pada pizza hut cabang simpang lima. Journal of Management, 1(1).

Khamis, F. \& AbRashid, R. (2018). Service quality and customer's satisfaction in Tanzania's Islamic banks: A Case Study at People's Bank of Zanzibar (PBZ). Journal of Islamic Marketing, 9(6), 884-900.

Kominfo. "Bisnis E-Commerce Semakin Gurih". https://www.kominfo.go.id/content/detail/32999/bisnis-e-commerce-semakingurih/0/artikel, diakses pada tanggal 21 Agustus 2021.

Kotler, P. \& Keller, K. L. (2016). Marketing Management, 15e édition. NewJersy: Pearson Education.

Loomes, G. \& Sugden, R. (1982). Regret Theory: An Alternative Theory of Rational Choice under Uncertainty. Economic Journal, 92(368), 805-824.

Malhotra, N. K. (2015). Essentials of marketing research: A hands-on orientation. Essex: Pearson.

Maria, I., Wijaya, V. \& Keni. (2021). Pengaruh Information Quality dan Service Quality terhadap Perceived Value dan Konsekuensinya terhadap Customer Engagement Behaviour Intention (Studi pada Social Commerce Instagram). Jurnal Muara Ilmu Ekonomi dan Bisnis, 5(2), 321-334. https://doi.org/10.24912/jmieb.v5i2.12276

Oghuma, A. P., Libaque-Saenz, C. F., Wong, S. F., \& Chang, Y. (2016). An expectationconfirmation model of continuance intention to use mobile instant messaging. Telematics and Informatics, 33(1), 34-47. https://doi.org/10.1016/j.tele.2015.05.006

Oliver, R. L. (1980). A Cognitive Model of the Antecedents and Consequences of Satisfaction Decisions. Journal of Marketing Research, 17(4), 460-469.

Oscar, Y. \& Keni, K. (2019). Pengaruh Brand Image, Persepi Harga, Dan Service Quality Terhadap Keputusan Pembelian Konsumen. Jurnal Muara Ilmu Ekonomi dan Bisnis, 3(1), 20-28.

Sutanto \& Keni. (2020). Pengaruh Service Quality, Service Convenience, dan Perceived Price and Fairness terhadap Loyalitas Nasabah Bank dengan Kepuasan Nasabah sebagai Variabel Mediasi. Jurnal Manajemen Bisnis dan Kewirausahaan, 5(2), 129-134.

Tata, S. V., Prashar, S., \& Parsad, C. (2020). Examining the influence of satisfaction and regret on online shoppers' post-purchase behaviour. Benchmarking: An International Journal. https://doi.org/10.1108/BIJ-06-2020-0332

Wang, M. M. \& Wang, J. J. (2019). Understanding Solvers' Continuance Intention in Crowdsourcing Contest Platform: An Extension of Expectation-Confirmation Model. $J$. Theor. Appl. Electron. Commer. Res., 14(3), 17-33.

We Are Social. (2021). "Digital 2021". https://wearesocial.com/digital-2021, diakses pada tanggal 21 Agustus 2021.

Yousapronpaiboon, K. (2014). SERVQUAL: Measuring higher education service quality in Thailand. Procedia-Social and Behavioral Sciences, 116, 1088-1095. https://doi.org/10.1016/j.sbspro.2014.01.350 